\title{
Электрооптический модулятор на основе полупроводниковой гетероструктуры с поверхностной дифракционной решеткой для управляемой угловой развертки лазерного луча
}

Золотарев В.В., Шашкин И.С., Соболева О.С., Головин В.С., Лешко А.Ю., Капитонов В.А., Слипченко С.О., Пихтин Н.А.

ФТИ им. А.Ф. Иоффе, 194021, Санкт-Петербург, Политехническая ул., 26

DOI 10.34077/Semicond2019-428

Представлен подход, позволяющий оптимизировать параметры конструкции чипа-модулятора на основе полупроводниковых гетероструктур с поверхностной дифракционной решеткой, обеспечивающие максимальную энергетическую эффективность, поле зрения и угловое разрешение для углового сканирования пространства лазерным лучом (рис. 1). Полностью электрическое сверхбыстрое управление лазерным лучом широко востребовано для современных задач беспилотного управления транспортными средствами, построения 3D карт, проекционных технологий. Управление оптическими параметрами волновода диодной гетероструктуры с помощью квантово-размерного эффекта Штарка позволяет управлять условиями дифракции излучения на поверхностной дифракционной решетки и, как следствие, углом вывода лазерного луча [1].

Показано, что при выборе параметров поверхностной дифракционной решетки (период, фактор оптического ограничения для выбранной волноводной структуры, скважность и протяженность) критически важным является работа при углах вывода максимально близких к углу полного внутреннего отражения. Установлено, что максимальная энергетическая

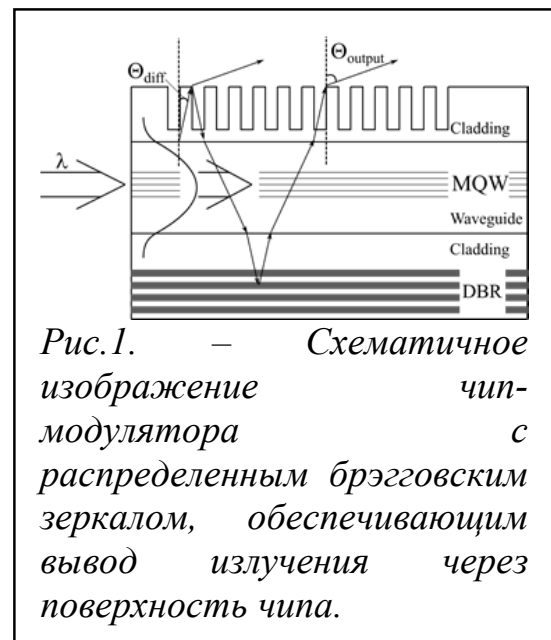
эффективность обеспечивается за счет использования дополнительного брэгговского зеркала со стороны подложки, которое обеспечивает возврат и вывод излучения, отраженного от границы раздела решетка/воздух. С данной целью необходимо развернуть угол вывода излучения первого порядка дифракции за счет увеличения периода дифракционной решетки. Увеличение периода приводит к появлению второго порядка дифракции. Распределение мощности между двумя порядками дифракции регулируется фактором заполнения штриха решетки. Для снижения оптических потерь дифракции почти до нуля для второго порядка дифракции необходимо использовать форму штриха в виде меандра.

Показано, что использование полупроводниковой гетероструктуры с набором туннельносвязанных квантовых ям, позволяющих модулировать модальный эффективный показатель преломления волноводной моды на $\Delta \mathrm{n}=0.007$, с поверхностной дифракционной решеткой в форме меандра и периодом $317 \mathrm{Hм}$, обеспечивает сканирование поля зрения 5 градусов с разрешением в 130 точек на длине волны 782 нм с эффективностью более $70 \%$.

«Исследование выполнено за счет гранта Российского научного фонда (проект №17-79-10339)»

[1] И.С. Шашкин, О.С. Соболева, П.С. Гаврина, В.В. Золотарев, С.О. Слипченко, Н.А. Пихтин. ФТП 52, 1491, (2018) 